\title{
Implementasi Kebijakan Publik Pelaporan Pemerintah Berbasis Akrual (Studi Kasus di Kantor Pelayanan Perbendaharaan Negara Malang)
}

\author{
Rengga Bayu Widiprana, Unti Ludigdo, Rosidi ${ }^{\text {a }}$ * \\ ${ }^{a}$ Universitas Brawijaya, Malang, Jawa Timur, Indonesia
}

\section{INFORMASI ARTIKEL}

\section{Article history:}

Dikirim tanggal: Juli 2017

Revisi pertama tanggal: Juli 2017

Diterima tanggal: Juli 2017

Tersedia online tanggal: Juli 2017

Keywords: accrual bases, Edward III theory, government reporting, policy implementation, LKPP, KPPN

\section{ABSTRACT}

This study aims to describe the implementation of accrual based reporting policy on LKPP-KPPN Malang with the Policy Implementation Theory of Edward III (1980) as an analytical tool on supporting and inhibiting factors of implementation in internal KPPN Malang. This research uses qualitative research method with case study research model. The results showed that in implementing the policy, KPPN Malang undertook the following steps: preparation (establishment of reconciliation team and LKPP compilers, policy socialization), implementation (report reconciliation, coordination with work unit), measurement (reconciliation of reconciliation balance and internal KPPN ), and reporting (report presentation, report analysis and CALK compilation). The supporting factor of implementation comes from communication and financial resources, while the inhibiting factors come from human resources, equipment resources, dispositions and bureaucratic structures.

\section{INTISARI}

Penelitian ini bertujuan untuk mendeskripsikan implementasi kebijakan pelaporan pemerintah berbasis akrual pada LKPP-KPPN Malang, dengan Teori Implementasi Kebijakan dari Edward III (1980) sebagai alat analisis faktor pendukung dan penghambat implementasi dari internal KPPN Malang. Penelitian ini menggunakan metode penelitian kualitatif dengan model penelitian studi kasus. Hasil penelitian menunjukkan bahwa dalam implementasi kebijakan, KPPN Malang melakukan langkah-langkah: persiapan (pembentukan tim rekonsiliasi dan penyusun LKPP, sosialisasi kebijakan), pelaksanaan (rekonsiliasi laporan, koordinasi dengan satuan kerja), pengukuran (pencocokan saldo hasil rekonsiliasi dan lintas seksi internal KPPN) dan pelaporan (penyajian laporan, analisa laporan dan penyusunan CALK). Faktor pendukung implementasi berasal dari komunikasi dan sumber daya finansial, sedangkan faktor penghambat berasal dari sumber daya manusia, sumber daya peralatan, disposisi dan struktur birokrasi.

2017 FIA UB. All rights reserved.

\section{Pendahuluan}

Penerapan basis akrual pada pelaporan keuangan sektor publik telah banyak dilaksanakan di berbagai Negara, seperti Australia (Churchill, 1992), Selandia Baru (Cortes, 2006), Inggris (Cortes, 2006), Nepal
(Adhikari dan Mellemvik, 2011), dan beberapa Negara lainnya. Akuntansi basis akrual akan menghasilkan laporan keuangan yang lebih berguna, karena mencerminkan keadaan sebenarnya dari aktivitas pemerintah. Hal ini akan meningkatkan kegunaan laporan keuangan baik sebagai alat pertanggungjawaban maupun

\footnotetext{
* Corresponding author. Tel.: +62-896-7503-7164; e-mail: renggabayuwidiprana@ gmail.com
} 
pengambil keputusan (Kim, et al., 2005; Mack \& Ryan, 2007). Negara Indonesia telah membulatkan tekad untuk menerapkan akuntansi basis akrual di tahun 2015. Direktur Jenderal Perbendaharaan, Bapak Marwanto Harjowiyono bahkan menyatakan bahwa Indonesia menjadi Negara pertama di Asean yang menerapkan akuntansi basis akrual (www.kemenkeu.go.id).

Di Negara Indonesia, Kantor Pelayanan Perbendaharaan Negara (KPPN) berperan dalam penyusunan Laporan Keuangan Pemerintah Pusat (LKPP). Sebagai entitas awal penyusun LKPP, berbagai usaha dilakukan oleh KPPN untuk menerapkan akuntansi basis akrual pada laporan keuangan. Usaha ini secara garis besar menerapkan apa yang ada di dalam Transition to Accrual Accounting dari Abdul Khan dan Stephen Mayes (2007): usaha di bidang sumber daya manusia (SDM), kebijakan dan teknologi.

Namun dengan berbagai usaha dalam implementasi pelaporan berbasis akrual, kendala muncul dengan belum bisa diterapkan secara sempurna basis akrual pada laporan keuangan. Kendala ini muncul dari berbagai faktor: dimulai dari kualitas SDM; sikap resistensi karena perubahan basis akuntansi dikenalkan ke publik dan operasionalisasinya tidak sesuai dengan keinginan publik (Arnaboldi \& Lapsley, 2004; Siti-Nabiha \& Scapens, 2005); komitmen dan dukungan dari pemimpin yang menjadi titik krusial dalam perubahan basis akuntansi (Athukorala \& Reid, 2003); ketidakpastian aplikasi penunjang pelaporan berbasis akrual. (SPAN dan SAKTI); dan kesulitan pemahaman basis akrual yang berakibat pada penurunan kualitas laporan keuangan (Nesbakk, 2010).

Semua kendala dalam implementasi basis akrual berakibat pada terlambatnya penyelesaian LKPP pada awal 2015. LKPP Bulan Januari-Maret terbengkalai selama 4 bulan. Ketua BPK-Bapak Hary Azhar Aziz menyatakan LKPP Nasional Tahun 2015 mengalami penurunan kualitas laporan keuangan (www.bpk.go.id). Bayangan kegagalan penerapan basis akrual muncul, seperti Nepal yang kekurangan sumber daya yang berkualitas (Adhikari dan Mellemvik, 2011).

Kendala dalam implementasi pelaporan basis akrual merupakan tantangan bagi KPPN yang juga dituntut menjadi guru bagi satker Kementerian Negara/Lembaga (Kep. Dirjen Perbendaharaan No. 239/PB/2015 tentang Rencana Strategis Ditjen Perbendaharaan Tahun 20152019). KPPN Malang sebagai objek penelitian merupakan KPPN pertama yang meraih penghargaan Kantor Pelayanan Percontohan (KPPc) tingkat Kementerian Keuangan di tahun 2013, predikat WBBM (Wilayah Birokrasi Bersih dan Melayani) dari Kemen. PAN\&RB pada 2014 dan memiliki sertifikat ISO 9001:2008 di 2015. Namun KPPN Malang belum bisa berbicara banyak dalam penyusunan LKPP. Pada tahun 2015, KPPN Malang menempati posisi ke-14 dari 15
KPPN se-Jawa Timur. Posisi terbaik ada di posisi ke-10 dari 15 KPPN pada tahun 2014. (Kepdirjen Perbendaharan No.326/PB/2015; Kep Kanwil Perbendaharaan Prop. Jatim No.145/WPB.16/2016).

Tabel 1

Peringkat LKPP KPPN Malang Tingkat Nasional dan Kanwil DJPB Propinsi Jawa Timur

Tahun 2012-2015

\begin{tabular}{|c|c|c|c|c|}
\hline Tingkat & 2012 & 2013 & 2014 & 2015 \\
\hline Nas & $\begin{array}{c}152 \\
\text { dari } \\
178 \\
\text { KPPN }\end{array}$ & $\begin{array}{c}148 \\
\text { dari } \\
178 \\
\text { KPPN }\end{array}$ & $\begin{array}{c}140 \\
\text { dari } \\
178 \\
\text { KPPN }\end{array}$ & $\begin{array}{c}\text { (mulai } 2015 \\
\text { pemeringkatan } \\
\text { LKPP hanya } \\
\text { per Kanwil) }\end{array}$ \\
\hline $\begin{array}{c}\text { Kanwil } \\
\text { DJPB } \\
\text { Prop. } \\
\text { Jawa } \\
\text { Timur }\end{array}$ & $\begin{array}{c}15 \\
\text { dari } \\
15 \\
\text { KPPN }\end{array}$ & $\begin{array}{c}11 \\
\text { dari } \\
15 \\
\text { KPPN }\end{array}$ & $\begin{array}{c}10 \\
\text { dari } \\
15 \\
\text { KPPN }\end{array}$ & $\begin{array}{c}14 \text { dari } 15 \\
\text { KPPN }\end{array}$ \\
\hline
\end{tabular}

Sumber: Kepdirjen Perbendaharaan No.191/PB/2013; Kepdirjen Perbendaharaan Nomor 248/PB/2014; Kepdirjen Perbendaharan No.326/PB/2015; Kep Kanwil Perbendaharaan Prop. Jatim No.145/WPB.16/2016.

Beberapa penelitian terkait implementasi pelaporan berbasis akrual masih banyak berfokus pada persiapan implementasi pelaporan berbasis akrual di pemerintah daerah. (Asfiansyah, 2014; Langelo, 2015; Muttaqin, 2015; Sari, 2015; dan Rahmawati, 2016). Selain itu, kendala yang dihadapi KPPN dalam implementasi pelaporan berbasis akrual (tingkat pemahaman dan kesulitan implementasi pelaporan berbasis akrual oleh SDM di KPPN; aplikasi yang perlu penyempurnaan; praktek dari petunjuk teknis kebijakan yang bisa beragam), pada dasarnya berasal dari internal organisasi dan dapat dikelompokkan menjadi 4 (empat) faktor sebagaimana di dalam Teori Edward III (1980). Implementasi pelaporan keuangan basis akrual pada KPPN harus memperhatikan faktor pendukung dan penghambat dari internal organisasi, yaitu komunikasi, sumber daya, sikap birokrasi/pelaksana dan struktur organisasi termasuk tata aliran kerja birokrasi.

Oleh karena itu, gap penelitian terdahulu akan diisi pada penelitian ini dengan melakukan penelitian pada objek yang telah menerapkan pelaporan keuangan berbasis akrual yaitu LKPP pada KPPN Malang. Implementasi pelaporan berbasis akrual akan dilihat sebagai kebijakan publik dan akan dilihat faktor pendukung dan penghambat implementasi kebijakan dari sisi internal KPPN Malang sesuai Teori Implementasi Kebijakan Publik dari George C. Edward III (1980).

\section{Teori}

\subsection{Teori Perubahan Organisasi-Kurt Lewin (1951)}

Kurt Lewin (1951) menyebutkan organisasi bergerak dari satu tahap yang sudah tetap ke tahapan yang 
lain, melalui serangkaian tahapan yang telah ditentukan dan bergeraknya organisasi dari tahap yang sudah tetap ke tahapan lainnya terjadi karena adanya tekanan-tekanan terhadap organisasi, individu, atau kelompok. Lewin membagi tahapan perubahan organisasi ini menjadi tiga tahap pada gambar berikut:

Gambar 1

Tiga Tahapan Perubahan Organisasi dari Kurt Lewin

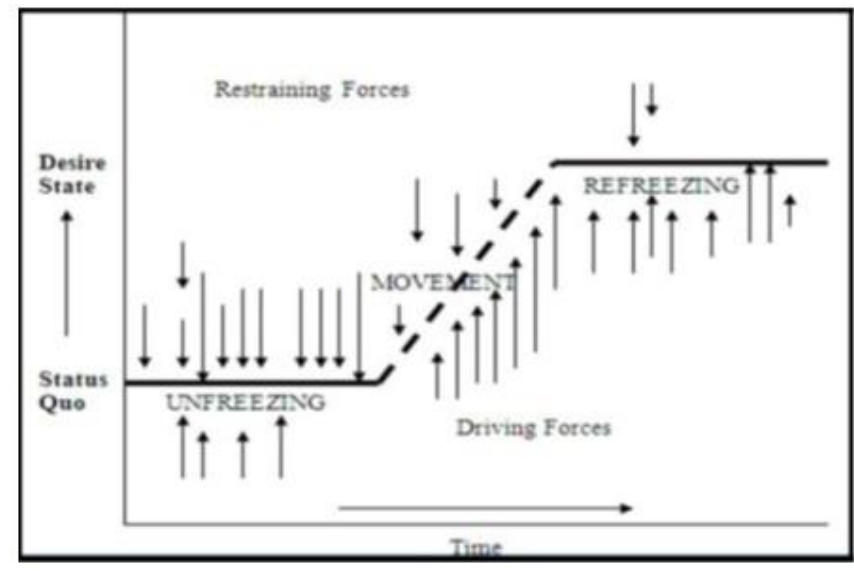

Sumber : Kurt Lewin (1951)

Tahapan awal perubahan (unfreezing) merupakan suatu proses penyadaran tentang perlunya atau adanya kebutuhan untuk berubah. Tahapan proses transisi (movement) merupakan langkah yang berupa tindakan dengan memperkuat driving forces maupun memperlemah resistances. Yang terakhir adalah tahapan keberlanjutan (refreezing) adalah upaya membawa kembali organisasi kepada keseimbangan yang baru dengan mengembangkan new self concept \& identity dan new interpersonal relationships agar perilaku yang baru tetap berjalan. (Lewin, 1951).

\subsection{New Institusionalism Theory (1967)}

New institutionalism Theory (NIT) dalam studi organisasi terkait dengan keberadaan struktur suatu organisasi yang yang dipengaruhi oleh tempat organisasi berada. Dalam teori ini, organisasi dibentuk oleh berbagai fenomena yang terjadi di lingkungannya dan cenderung mirip (isomorphic) dengan lingkungan tersebut (Berger dan Luckmann, 1967 sebagaimana dirujuk oleh Sari, 2015).

Tiga (3) mekanisme yang menyebabkan terjadinya institutional isomorphism, yaitu 1).coercive isomorphism, 2).Mimetic isomorphism, dan 3).normative isomorphism (DiMaggio dan Powell, 1983; Carruthers, 1995; Lippi, 2000). Pertama, coercive (paksaan), yaitu akibat tekanan-tekanan formal ataupun informal yang diterima suatu organsasi, yang mana tekanan tersebut dari organisasi lain ataupun harapan masyarakat sekitar organisasi berada. Selain adanya suatu paksaan, organisasi juga menghadapi suatu ketidakpastian, dimana hal ini menjadi sebuah tekanan yang kuat untuk melakukan perubahan organisasi dengan cara mengimitasi (mimetic) organisasi lain. Normative isomorphism merupakan bentuk pendorong ketiga dimana pengaruhnya berasal dari profesionalisasi.

\subsection{Teori Implementasi Kebijakan Publik dari George C. Edward III (1980)}

Di dalam teori Implementasi Kebijakan Publik dari George C. Edward III (1980), suatu kebijakan publik akan sukses diimplementasikan jika melihat lebih dahulu pada dua pertanyaan, faktor apa yang mendukung dan menghambat keberhasilan implementasi kebijakan. Kemudian dari dua pertanyaan ini dirumuskan empat faktor yang merupakan syarat utama keberhasilan proses implementasi, yakni komunikasi, sumber daya, sikap birokrasi/pelaksana dan struktur organisasi termasuk tata aliran kerja birokrasi

\section{Gambar 2}

Faktor Penentu Keberhasilan Implementasi Kebijakan menurut Edward III

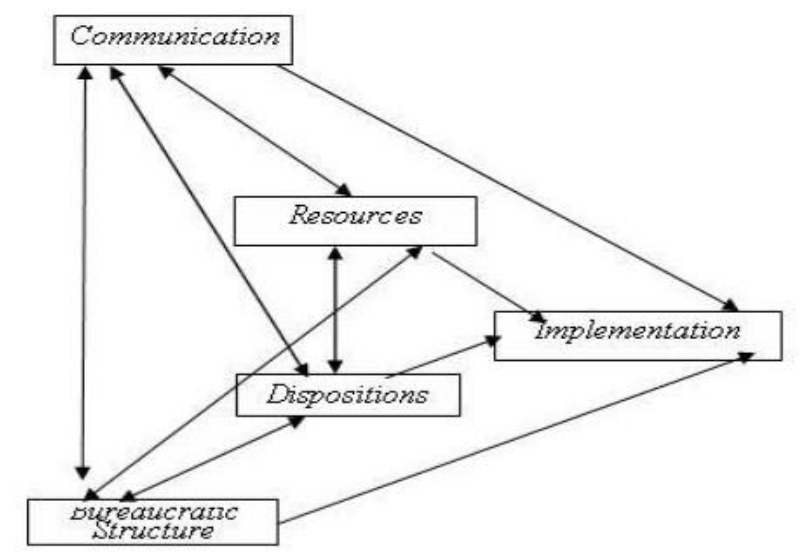

Sumber: Edward III (1980)

Menurut Edward III (1980), komunikasi diartikan sebagai "proses penyampaian informasi komunikator kepada komunikan". Informasi mengenai kebijakan publik perlu disampaikan kepada pelaku kebijakan agar para pelaku kebijakan dapat mengetahui apa yang harus mereka persiapkan dan lakukan untuk menjalankan kebijakan tersebut sehingga tujuan dan sasaran kebijakan dapat dicapai sesuai dengan yang diharapkan. Edward III (1980) mengemukakan faktor sumber daya mempunyai peranan penting dalam implementasi kebijakan. Sumber daya tersebut meliputi sumber daya manusia, sumber daya anggaran, dan sumber daya peralatan. Disposisi menurut Edward III (1980) adalah "kemauan, keinginan dan kecenderungan para perlaku kebijakan untuk melaksanakan kebijakan tadi secara sungguh-sungguh sehingga apa yang menjadi tujuan kebijakan dapat diwujudkan". Edward III (1980) menyatakan bahwa "implementasi kebijakan bisa jadi masih belum efektif 
karena ketidakefisienan struktur birokrasi”. Struktur birokasi mencakup aspek-aspek seperti struktur birokrasi, pembagian kewenangan, hubungan antara unitunit organisasi dan sebagainya.

\subsection{Pemilihan Teori Edward III sebagai Alat Analis}

Berdasarkan beberapa teori organisasi di atas, peneliti tidak memilih teori Perubahan Organisasi dari Lewin (1951) dikarenakan peneliti akan fokus pada implementasi kebijakan bukan proses perubahan organisasi. Peneliti tidak memilih New Institutional Theory, karena teori ini berfokus pada tahap adaptasi (isomorphism) bukan implementasi kebijakan.

Peneliti akan memilih Teori Implementasi Kebijakan Publik dari Edward III (1980) karena beberapa pertimbangan berikut, pertama; Teori ini sesuai dengan kondisi permasalahan dimana implementasi dapat dimulai dari dua pernyataan yakni apa persyaratan dan apa halangan untuk suksesnya impelementasi kebijakan? Edward III (1980) menjawab dua pertanyaan ini dengan empat faktor krusial dalam implementasi kebijakan publik, yaitu komunikasi, sumber daya, disposisi dan struktur birokrasi. Kedua; Pemilihan teori Edward III (1980) didasarkan pada pertimbangan bahwa teori ini mampu menjelaskan unsur pendukung dan penghambat keberhasilan suatu implementasi program ditinjau dari sisi internal organisasi yang selaras dengan kajian yang ingin dilakukan oleh peneliti. Ketiga; Pemilihan teori ini pun didasarkan pada pertimbangan bahwa secara substansial, keempat faktor implementasi diarahkan ke aparat birokrasi pemerintahan. Model yang dikemukakan Edward III (1980) bersifat top down dan cocok untuk diimplemementasikan pada level birokrasi yang terstruktur pada suatu lembaga pemerintahan di mana setiap level hierarki mempunyai peran dan fungsi dalam penjabaran kebijakan.

\section{Metode Penelitian}

Penelitian ini menggunakan pendekatan penelitian kualitatif dengan model penelitian studi kasus dari Yin (2013). Yin (2013:1) mengungkapkan bahwa studi kasus merupakan strategi penelitian yang cocok untuk beberapa kondisi. Pertama, pertanyaan penelitian berkenaan dengan how atau why. Kedua, peneliti hanya memiliki sedikit peluang untuk mengontrol peristiwa-peristiwa yang akan diselidiki. Ketiga, fokus penelitian terletak pada fenomena kontemporer (masa kini) di dalam konteks kehidupan nyata. Teknik pengumpulan data melalui participant observation, wawancara, dan dokumentasi. Informan kunci dalam penelitian adalah Kepala KPPN Malang, Kepala Seksi Vera KPPN Malang dan Penyusun LKPP KPPN Malang.

Analisa data mengadaptasi teknik analisa data studi kasus dari Yin (2014). Teknik analisa ini memiliki tahapan penjodohan pola di mana posisi teori Edward III (1980) terdapat pada tahapan penjodohan pola. Data empirik akan dijodohkan dengan data yang diprediksi berdasarkan operasionalisasi 4 faktor dari Teori Edward III (1980), yakni komunikasi, sumber daya, disposisi dan struktur birokrasi. Teknik analisa data studi kasus dari Yin (2014) memiliki tiga langkah, yaitu (a) Penjodohan Pola dengan menggunakan alat analisa Teori Edward III; (b) Pembuatan Eksplanasi; dan (c) Penarikan Kesimpulan/Verifikasi.

\section{Hasil Penelitian dan Pembahasan}

Masa implementasi pelaporan basis akrual di KPPN Malang telah dimulai pada penyusunan LKPP tahun 2015. Selama dua periode pelaporan, KPPN Malang berpedoman pada PP No. 71 Tahun 2010 dan PMK No.177/PMK.05/2015 sebagai kebijakan pokok dalam pelaporan berbasis akrual. Kedua peraturan ini telah menghasilkan laporan berbasis akrual dalam LKPP KPPN Malang, diantaranya Laporan Operasional, Laporan Perubahan Ekuitas dan Neraca. LKPP KPPN Malang tetap menampilkan Laporan Realisasi Anggaran, Laporan Perubahan Saldo dan Laporan Arus Kas sebagai sarana pertanggungjawaban APBN yang masih berbasis kas.

\subsection{Tahapan Implementasi Kebijakan Pelaporan Berbasis Akrual di KPPN Malang}

Dalam implementasi kebijakan pelaporan basis akrual, KPPN Malang berpedoman pada Kepdirjen Perbendaharaan No. 287/PB/2015 mengenai Standar Operasional Prosedur KPPN. Hasil penelitian menunjukkan, KPPN Malang dalam implementasi kebijakan melakukan langkah-langkah berikut: persiapan, pelaksanaan, pengukuran dan pelaporan. Pembagian langkah-langkah kegiatan berdasarkan timeline dalam satu periode pelaporan.

\subsubsection{Persiapan Pelaksanaan Kebijakan Pelaporan Basis Akrual}

Tahapan persiapan dilakukan KPPN Malang di awal periode pelaporan. KPPN Malang dalam tahap persiapan implementasi pelaporan basis akrual, membagi tahapan ini menjadi: pembentukan tim rekonsiliasi dan penyusun LKPP; sosialisasi kebijakan; dan pelatihan satuan kerja. Perkembangan penerapan basis akrual terlihat pada proses sosialisasi dan pelatihan, di mana telah terlihat proses adjustment (jurnal penyesuaian) satker pada akun belanja pegawai dan belanja modal. Berikut Berikut kutipan wawancara dengan Ibu Aaz (tim penyusun LKPP/helpdesk KPPN Malang):

"Sosialisasinya gak hanya satu arah mas, dua arah. Kita kasih materi, terus mereka dipersilahkan 
bertanya. Rata-rata udah paham kok akrual. Pokoknya kita juga udah wanti-wanti di belanja pegawai, kayak rapel gaji sama uang muka belanja modal".

\subsubsection{Pelaksanaan Kebijakan Pelaporan Berbasis Akrual}

Tahapan pelaksanaan memainkan peranan penting dalam menentukan output laporan berbasis akrual. KPPN Malang membagi tahapan ini menjadi beberapa langkah: rekonsiliasi laporan dan koordinasi dengan satuan kerja. Rekonsiliasi sebagai kendala dalam awal pelaporan basis akrual telah diatasi dengan adanya aplikasi $e$-rekon secara online dan mandiri. Satuan kerja diberikan kemudahan dalam proses rekonsiliasi, karena tanggal pelaksaaan rekon yang merupakan hasil koordinasi antara kementerian/lembaga dengan Direktorat Akuntasi dan Pelaporan - Kementerian Keuangan. Berikut kutipan wawancara dengan saudara Ndaru:

"Sekarang rekonsiliasinya sudah enak mas. Sudah mandiri, online, gak perlu nunggu lama lagi kayak dahulu. Namanya e-rekon. Tanggal rekonsiliasinya juga berdasarkan hasil koordinasi pimpinan $K / L$ dengan kantor pusat kita. Pokoknya enak udah mas".

Koordinasi sebagai sarana komunikasi kebijakan (Edward III, 1980) dilakukan dengan memanfaatkan media sosial, seperti whatsapp, facebook dan website KPPN Malang.

\subsubsection{Pengukuran Pelaksanaan Kebijakan Pelaporan Berbasis Akrual}

Tahapan pengukuran dilakukan untuk mengukur capaian implementasi kebijakan. KPPN Malang melakukan tahapan ini dengan pencocokan saldo hasil rekonsiliasi dari satuan kerja dan antar seksi di KPPN Malang. Pencocokan saldo hasil rekonsiliasi dari satuan kerja dilakukan dalam rangka menjamin ketepatan angka-angka hasil adjustment dari satker. Perkembangan aplikasi SAIBA (Sistem Akuntansi Instansi Berbasis Akrual) satker menunjukkan kemudahan dalam proses adjustment. Untuk ini, diperlukan pencocokan saldo hasil rekonsiliasi sebagai jaminan ketepatan angka rekonsiliasi tersebut. Pencocokan saldo antar seksi diperlukan dalam menyamakan saldo yang ada pada laporan di setiap seksi. Hal ini diperlukan untuk menjamin ketepatan angka sebelum memulai tahapan pelaporan dalam LKPP. Berikut hasil wawancara dengan informan (Bapak Md petugas rekonsiliasi):

"Sejak ada basis akrual ini mas, jadi butuh lebih hati-hati nyocokin saldo. Terutama sama seksi PD, karena kan mereka melakukan pembayaran ke satker. Nah kadang ada yang tiba-tiba diakrualin, kita nyocokin lagi. Pokoknya ya berubah semua".

\subsubsection{Pelaporan Pelaksanaan Kebijakan Pelaporan Berbasis Akrual}

Tahap pelaporan kebijakan basis akrual merupakan tahap KPPN Malang menghasilkan LKPP. Pada tahapan ini, output dari pelaporan basis akrual telah berwujud nyata dan menyeluruh. Tahapan ini dimulai dari penyajian laporan, analisa laporan dan terakhir adalah penyusunan Catatan Atas Laporan Keuangan.

Laporan Keuangan Pemerintah Pusat KPPN Malang Tahun 2015 dan 2016 telah disajikan sesuai dengan kebijakan pelaporan basis akrual dalam PP No. 71 Tahun 2010. Penyajian laporan keuangan yang menarik untuk dilihat terdapat pada membandingkan Laporan Operasional dengan Laporan Realisasi Anggaran dan adanya penggunaan dua basis dalam penyusunan Neraca. LRA dan LO disusun dengan basis akuntansi yang berbeda walau sekilas memiliki format yang hampir sama. Sedangkan penggunaan dua basis dalam penyusunan Neraca dilakukan dalam rangka memenuhi pertanggungjawaban kas umum negara (dengan Neraca Basis Kas) dan penilaian real aset dan kewajiban (dengan Neraca Basis Akrual).

Analisa laporan dilakukan dalam rangka menjamin ketepatan angka-angka antar laporan yang memiliki keterkaitan. Setelah melalui tahapan analisa, KPPN Malang menyusun CALK untuk memberikan informasi tambahan terkait penyusunan LKPP. Perkembangan pelaporan basis akrual secara umum menunjukkan peningkatan dan kemudahan dibandingkan tahun 2015. Namun CALK yang disusun belum menunjukkan informasi akrual dikarenakan belum ada ketentuan penyusunan CALK LO dan Neraca.

\subsection{Analisis Implementasi Kebijakan Pelaporan Berbasis Akrual pada KPPN Malang}

Untuk menunjang keberhasilan dalam implementasi kebijakan pelaporan basis akrual, dilakukan analisis implementasi kebijakan pelaporan basis akrual dengan alat analisis Teori Edward III (1980) di semua tahapan implementasi kebijakan. Model ini mengelompokkan faktor pendukung dan penghambat keberhasilan implementasi dari sisi internal organisasi menjadi 4 faktor: komunikasi, sumber daya, disposisi, dan struktur birokrasi.

\subsubsection{Komunikasi}

Dalam proses komunikasi, KPPN Malang telah memenuhi dimensi transmisi, kejelasan dan konsistensi sebagaimana di dalam Teori Edward III (1980). Dimensi transmisi dilakukan KPPN Malang dengan melakukan 
sosialisasi kebijakan ke satuan kerja dan ke dalam (pegawai) KPPN Malang. Berikut hasil wawancara dengan informan (Bapak Md-tim rekonsiliasi) :

"Paling sering sosialisasi ke satker mas. Minimal 2 tahun sekali, malah waktu persiapan akrual dulu bisa 4 kali. Pokoknya alhamdulillah mas, satker banyak yang antusiasi kalau diadakan sosialisasi". Untuk menjamin kejelasan komunikasi, KPPN Malang selalu mendokumentasikan semua petunjuk teknis dalam pelaksanaan kebijakan pelaporan basis akrual. Sedangkan dalam menjamin konsistensi komunikasi, KPPN Malang selalu intensif dalam melakukan koordinasi. Koordinasi ini tidak hanya ke satker, tapi juga ke internal (pegawai), dan ke atas (Kanwil DJPB Propinsi Jawa Timur dan Kantor Pusat DJPB).

Koordinasi ke internal (pegawai) KPPN Malang, termasuk dalam komunikasi horizontal. Komunikasi horizontal diperlukan sebagai pertukaran pesan diantara orang-orang yang sama tingkatan otoritasnya di dalam organisasi (Arni, 2002:121). Komunikasi horizontal memanfaatkan acara Gugus Kendali Mutu (GKM) yang merupakan acara pertemuan seluruh pegawai untuk membahas dan mengkoordinasikan kembali hal penting/hot issue terkait pelaksaan pekerjaan. GKM dilaksanakan setiap Rabu sore, selama 2 jam. Materi yang ada merupakan materi terupdate dan semua diisi semua seksi secara bergiliran. Berikut hasil wawancara dengan informan (Ndaru-penyusun LKPP):

"Koordinasi ke dalam kita lakukan dengan memanfaatkan GKM mingguan mas. GKM nya tiap rabu sore dan yang ngisi semua seksi secara bergantian. Materinya juga tergantung hot issue. Kalau dulu seksi vera hampir tiap GKM isinya akrual, jurnal penyesuaian, pokoknya full akrual. Kalau sekarang ke prosedur pelaporannya. Pokoknya terupdate mas".

Koordinasi yang dilakukan ke Kanwil DJPB Propinsi Jawa Timur dan Kanpus DJPB termasuk ke dalam komunikasi ke atas. Komunikasi ke atas diperlukan dalam rangka memberikan umpan balik atas komunikasi dari atas dan memberikan isu-isu dan masalah terbaru yang dihadapi (Ivancevich, et al., 2006:121). Informan (Bapak Marjanto) mengungkapkan:

"Kalau koordinasi ke Kanwil sama kanpus ya sama, pakai medsos juga. Ada WA grup juga. Kalo Kanwil juga ngundang kita ke sana buat rakor, rata-rata sih semesteran. Sama Kanpus juga, LKPP Tahunan manggil kita buat rakor pelaporan".

Sedangkan komunikasi ke luar dilakukan dengan koordinasi ke satker, dengan memanfaatkan media sosial: whatsapp, facebook dan website KPPN Malang. Informan Ibu AAZ-tim penyusun LKPP mengungkapkan:
"Kalau satker mas, koordinasinya pakai medsos. WA, FB, web. Kebanyakan sih WA mas, soalnya kita punya WA grup. Hampir tiap hari lah WA grup kita gak pernah sepi".

Berdasarkan uraian di atas dapat disimpulkan bahwa komunikasi menjadi faktor pendukung dalam implementasi kebijakan. Dapat dilihat dari hasil komunikasi yang menimbulkan sikap akan perlunya basis akrual dalam pelaporan keuangan. Berikut ini hasil wawancara dengan Pjs. Kepala Seksi Vera (Bapak Marjanto):

"Alhamdulilah mas, memasuki tahun ketiga, akrual bukan hal asing lagi. Pokoknya semua perubahan akan selalu kita komunikasikan, karena kita lah yang nanti akan menularkannya ke stake holder kita".

\subsubsection{Sumber Daya}

\subsubsection{Sumber Daya Manusia}

Pada KPPN Malang, jumlah pegawai dapat dibilang cukup memadai dengan 43 personel. Komposisi pegawai KPPN Malang dapat dilihat pada tabel berikut:

Tabel 2

Komposisi Pegawai Berdasarkan Jenis Kelamin

\begin{tabular}{|c|c|c|}
\hline No & Jenis Kelamin & Jumlah \\
\hline 1 & Laki-laki & 19 \\
\hline 2 & Perempuan & 24 \\
\hline
\end{tabular}

Sumber : Kepegawaian KPPN Malang Tahun 2017

Tabel 3

Komposisi Pegawai Berdasarkan Usia

\begin{tabular}{|c|c|c|c|}
\hline No & Usia & Jenis Kelamin & Jumlah \\
\hline \multirow{2}{*}{1} & \multirow{2}{*}{$20-29$ tahun } & Laki-laki & 2 \\
& & Perempuan & 1 \\
\hline \multirow{2}{*}{2} & \multirow{2}{*}{$30-39$ tahun } & Laki-laki & 1 \\
& & Perempuan & - \\
\hline \multirow{2}{*}{3} & \multirow{2}{*}{$40-49$ tahun } & Laki-laki & 3 \\
& & Perempuan & 6 \\
\hline \multirow{2}{*}{4} & \multirow{2}{*}{$50-59$ tahun } & Laki-laki & 13 \\
& & Perempuan & 17 \\
\cline { 3 - 4 } & & & \\
\cline { 3 - 4 }
\end{tabular}

Sumber : Kepegawaian KPPN Malang Tahun 2017

Tabel 4

Komposisi Pegawai Berdasarkan Tingkat Pendidikan

\begin{tabular}{|c|c|c|c|}
\hline No & Usia & Jenis Kelamin & Jumlah \\
\hline \multirow{2}{*}{1} & \multirow{2}{*}{ SMA } & Laki-laki & 11 \\
& & Perempuan & 10 \\
\hline \multirow{2}{*}{2} & \multirow{2}{*}{ Diploma I } & Laki-laki & - \\
& & Perempuan & 1 \\
\hline \multirow{2}{*}{3} & \multirow{2}{*}{ Diploma III } & Laki-laki & 2 \\
& Perempuan & 4 \\
\hline 4 & Sarjana & Laki-laki & 5 \\
\hline
\end{tabular}




\begin{tabular}{|c|c|c|c|}
\hline No & Usia & Jenis Kelamin & Jumlah \\
\hline & & Perempuan & 9 \\
\hline 5 & Magister & Laki-laki & 1 \\
& & Perempuan & - \\
\hline
\end{tabular}

Sumber : Kepegawaian KPPN Malang Tahun 2017

Jumlah SDM di KPPN Malang telah cukup secara kuantitas dan kualitas, karena semua SDM merupakan pegawai hasil assessment KPPN Percontohan di tahun 2012. Semua SDM memiliki kompetensi minimal pada pemahaman peraturan dan teknologi informasi di bidang Keuangan Negara.

Komposisi SDM yang kebanyakan perempuan berusia di atas 50 tahun dan tingkat pendidikan SMA membuat pola mutasi menjadi kaku. Seorang penyusun LKPP baru dimutasi setelah menjalani masa kerja lebih dari 2 tahun. Hal ini juga menghambat dalam implementasi kebijakan, terutama pada analisa laporan keuangan yang kompleks, membutuhkan ketelitian dan waktu yang tidak sedikit. Pjs. Kepala Seksi Vera (Bapak Marjanto) menyatakan sebagai berikut:

"Ya mungkin kendalanya disini itu SDM ya mas, karena begini ini, kebanyakan ibu-ibu. Kalau disuruh nyusun LKPP ya kita maklum. Tapi Alhamdulilah mas, SDM penyusun LKPP di KPPN Malang sudah mumpuni. Mas Ndaru ini lulusan STAN. Pokoknya terbantu banget. Tapi dalam jangka panjang ya ketar-ketir juga kalau gak ada cadangannya seumpama Mas Ndaru di mutasi”.

Dalam pemenuhan tuntutan peran KPPN sebagai guru, semua SDM KPPN Malang harus dapat dioptimalkan. Dalam meningkatkan kompetensi SDM, perlu dilakukan mutasi pada penyusun LKPP. Mutasi menurut Wahyudi (1995) adalah perpindahan pekerjaan seseorang dalam suatu organisasi yang memiliki tingkat level yang sama dari posisi perkerjaan sebelum mengalami pindah kerja. Dengan mutasi, maka staf yang berkualitas dalam penyusunan LKPP akan menjadi banyak. Ditambah lagi semua SDM di KPPN Malang pada dasarnya merupakan pegawai yang telah lulus assessment di bidang Perbendaharaan dan Keuangan Negara. Kekhawatiran akan terjadinya mutasi pada satu pegawai utama penyusun LKPP akan hilang jika KPPN Malang memiliki banyak pegawai cadangan.

Masih dari sisi SDM, ditemukan jabatan Kepala Seksi Vera yang masih kosong selama lebih dari 6 bulan. Kekosongan ini diatasi dengan rangkap jabatan Kasi Vera oleh Kasi Bank. Di dalam Keputusan Menteri Negara PAN Nomor 63/Kep/M.PAN/7/2003 mengenai Pedoman Umum Penyelenggaraan Publik dinyatakan bahwa salah satu dari syarat layanan publik yang baik adalah adanya kepastian pejabat yang berwenang dan bertanggung jawab dalam memberikan pelayanan. Kekosongan jabatan Kasi Vera selain berbahaya dari sisi aturan, juga bisa menghambat implementasi kebijakan dalam jangka panjang. Darwin (1995) menyatakan hal penting dalam implementasi kebijakan adalah: pendayagunaan sumber; pelibatan orang atau sekelompok orang dalam implementasi; interpretasi; dan manajemen program. Ketiadaan pejabat pada Kasi Vera akan menghambat manajemen program dalam implementasi pelaporan basis akrual. Kasi yang bertugas sementara akan kesulitan dalam memanajemen implementasi kebijakan.

Kasi Vera yang definitif akan lebih bisa menjadi pemimpin bagi stafnya. Pemimpin dapat menjadi suporter bagi pelaksananya, tapi seorang atasan tidak peduli dengan tingkah laku pelaksananya (Tohidi dan Jabbari, 2012). Kasi Bank yang bertugas sementara juga memiliki kesibukan di seksinya. Sehingga wajar, jika ada kekhawatiran perhatian Beliau ke bawahannya akan terpecah.

Dari uraian di atas dapat disimpulkan bahwa faktor SDM menjadi faktor penghambat implementasi kebijakan. Hal ini berasal dari komposisi SDM yang kebanyakan perempuan berusia di atas 50 tahun dan menyebabkan mutasi pegawai berjalan kaku serta dibutuhkan segera pengisian jabatan pada Kasi Vera di KPPN Malang.

\subsubsection{Sumber Daya Finansial}

Pada KPPN Malang, seksi Vera sebagai penyusun LKPP memiliki porsi dana terbesar dalam DIPA KPPN Malang. Dengan dana ini, seksi Vera KPPN Malang akan memberikan output yang optimal dalam pelaporan basis akrual.

Tabel 5

DIPA KPPN Malang Tahun 2017

\begin{tabular}{|c|c|c|c|}
\hline No & Kegiatan & $\begin{array}{c}\text { Jumlah } \\
\text { Dana }\end{array}$ & \% \\
\hline 1 & $\begin{array}{c}\text { Layanan Pelaksanaan } \\
\text { Kuasa BUN di Daerah }\end{array}$ & 339.440 .000 & 5,97 \\
\hline 2 & LKPP Tingkat Kuasa BUN & 169.536 .000 & 2,98 \\
\hline 3 & Layanan Internal & 97.571 .000 & 1,71 \\
\hline 4 & Layanan Perkantoran & 5.084 .211 .000 & 89,34 \\
\hline & Total Dana dalam DIPA & 5.690 .758 .000 & 100 \\
\hline
\end{tabular}

Sumber : DIPA KPPN Malang Tahun 2017

Tabel 6

Rincian Dana Kegiatan LKPP-KPPN Malang Tahun 2017

\begin{tabular}{|c|c|c|c|}
\hline No & Sub Kegiatan & $\begin{array}{c}\text { Jumlah } \\
\text { Dana }\end{array}$ & \% \\
\hline 1 & Konsultasi dan Koordinasi & 28.120 .000 & 16,59 \\
\hline 2 & Rekonsiliasi Data & 18.000 .000 & 10,61 \\
\hline 3 & Penyusunan Laporan & 27.000 .000 & 15,93 \\
\hline 4 & Sosialisasi dan Bimtek & 96.416 .000 & 56,87 \\
\hline \multicolumn{2}{|c|}{ Total Dana } & 169.536 .000 & 100 \\
\hline
\end{tabular}

Sumber : DIPA KPPN Malang Tahun 2017 
Tahapan implementasi kebijakan yang mendapatkan sokongan dana terbesar adalah tahapan persiapan implementasi kebijakan (sosialisasi dan bimbingan teknis) sebagai jaminan keberhasilan tahapan selanjutnya. Dengan demikian, dapat disimpulkan faktor sumber daya finansial menjadi faktor pendukung dalam implementasi kebijakan di KPPN Malang. Dengan memanfaatkan sumber daya finansial yang ada, KPPN Malang masih bisa menambah satu kegiatan lagi, yaitu evaluasi dengan pemberian award kepada satker yang berprestasi. Dalam implementasi kebijakan yang baik, sering ada mekanisme insentif dan sanksi (Subarsono, 2009:12). Dengan mekanisme award, satuan kerja akan lebih terpacu dalam implementasi pelaporan basis akrual. Ukuran keberhasilan pelaporan basis akrual bisa dilakukan dengan melihat kualitas laporan satker berdasarkan PP No. 71 Tahun 2010.

\subsubsection{Sumber Daya Peralatan}

Di dalam implementasi kebijakan, peralatan memiliki peranan penting sebagai sarana mencapai tujuan kebijakan. Peralatan di KPPN Malang terhitung baik dan baru, seiring dengan berbagai predikat kontes pelayanan yang diraih. Namun faktor ini juga dapat menghambat implementasi pelaporan basis akrual di KPPN Malang karena hanya ada satu printer yang canggih di KPPN Malang, yaitu di seksi Vera. Dengan padatnya proses penyusunan LKPP, maka keberadaan printer yang hanya satu-satunya di seksi Vera akan berbahaya dalam jangka panjang.

Umur ekonomis printer di dalam Peraturan Menteri Keuangan No.96/PMK.03/2009 mengenai Jenis-jenis Harta yang Termasuk Dalam Kelompok Harta Berwujud Bukan Bangunan untuk Keperluan Penyusutan dinyatakan bahwa umur ekonomis printer hanya 4 tahun. Hal ini diperparah dengan penggunaan printer di seksi Vera secara beramai-ramai dengan seksi lain. Oleh karena itu, diperlukan tinjauan atas minimnya sarana printer dalam implementasi kebijakan pelaporan basis akrual di KPPN Malang.

\subsubsection{Disposisi}

Sikap baik dari para implementor akan menjamin lancarnya proses implementasi kebijakan. Pada level pelaksana KPPN Malang, terdapat disposisi yang kurang baik terkait keluhan pelaksana akan proses rekonsiliasi yang berubah-ubah setiap bulan. Berikut kutipan wawancaranya (Bapak MD):

"tanggal e-rekon itu antara 7 sampai 20. Dan tiap bulan selalu berubah-ubah, mengikuti hasil koordinasi dari Kantor Pusat dengan K/L. Bagi kami ya kadang jadi bingung mas kapan mau cut off, sama menjadwal nyusun LKPP nya”.
Keluhan juga muncul pada level pelaksana terkait lamanya proses pencocokan saldo antar seksi. Pada kegiatan ini, terjadi pertentangan kepentingan antar pegawai. Pegawai di seksi vera menginginkan adanya akses data langsung ke seksi lain, sedangkan pegawai seksi lain menginginkan kegiatan ini tetap ada sebagai mekanisme check and balance. Berikut kutipan wawancaranya (Ndaru-pegawai Seksi Vera):

"Walau koordinasi dengan seksi Bank dan PD baik mas, tapi ya tetap kalau ini membutuhkan waktu. Belum lagi kalau tiba-tiba seksi ini berubah, seksi itu berubah, ya kita posting lagi, nyocokin lagi. Pengennya sih kita punya akses langsung ke mereka".

Berikut kutipan wawancaranya (Ibu As-pegawai Seksi Bank):

"oh proses mencocokkan saldo ya mas. Iya itu seksi vera tiap bikin LKPP emang minta saldo LKP kami buat dicocokkan. Bagus itu mas, jadi saling mengkoreksi".

Di level Kepala Seksi Vera terjadi "kekosongan" jabatan Kepala Seksi selama 6 bulan. Jabatan ini sekarang diisi oleh Kepala Seksi Bank. Namun jika dibiarkan terlalu lama, dikhawatirkan akan mengurangi disposisi baik dari Kepala Seksi Bank. Masih pada level Kepala Seksi, terdapat hambatan terkait peringkat jabatan Kasi Vera yang satu tingkat lebih rendah dari Kasi lain. Hal ini berdampak pada take home pay yang diterima Kasi Vera lebih rendah dari Kasi lain. Take home pay yang diterima ini termasuk dalam insentif, dimana insentif menurut Gorda (2004:141) adalah suatu sarana memotivasi berupa materi, yang diberikan sebagai suatu perangsang ataupun pendorong dengan sengaja kepada para pekerja agar dalam diri mereka timbul semangat yang besar untuk meningkatkan produktivitas kerjanya dalam organisasi. Berikut kutipan wawancara dengan Bp. Marjanto (Pjs. Kasi Vera):

"Ya itu sudah lama mas, sejak Kemenkeu mulai menerapkan peringkat jabatan di 2008, Kepala Seksi Vera jadi berperingkat lebih rendah dibanding Kepala Seksi lain. Yang saya tahu waktu itu proses nyusun peringkatnya pakai jasa konsultan dari luar. Saya sih yakin mas, walau peringkatnya beda, ya Kepala Seksi Vera kan sudah tanggung jawabnya bikin LKPP. Ya harapan saya sebagai Kepala Seksi lain ya samakanlah. Kasihan juga sering lembur nyusun LKPP".

Masih pada level pimpinan, hasil penelitian juga menemukan penyebab kenapa peringkat LKPP KPPN Malang di Tahun 2015 mengalami penurunan. Penyebab dari menurunnya peringkat LKPP ini berasal dari kurangnya perhatian pimpinan terhadap penyusunan LKPP di tahun itu. Padahal tahun 2015 adalah masa awal penerapan basis akrual. Kepala KPPN Malang saat itu lebih memperhatikan persiapan KPPN Malang untuk 
mendapatkan sertifikat ISO 9001:2008 di 2015. Berikut kutipan wawancara dengan informan (Bapak Md):

"sebenarnya sudah bagus mas, waktu di tahun 2014 sudah lumayan naik ke peringkat 10. Tapi pas tahun 2015, pas mulainya basis akrual, pas banyakbanyaknya masalah, eh pas pula Kantor ini proses sertifikasi ISO. Ya udah, Kepala Kantornya agak mengorbankan penyusunan LKPP”.

Dapat kita lihat, dengan kurangnya komitmen pemimpin, sangat berpengaruh pada implementasi kebijakan. Untuk mencapai tujuan pelaporan basis akrual yang lebih baik, maka diperlukan kepemimpinan pada level Kepala Kantor dan Kepala Seksi Vera KPPN Malang. Terlebih lagi lokasi, kondisi dan sarana prasarana KPPN Malang yang strategis, membuat peluang KPPN Malang untuk mewakili Direktorat Jenderal Perbendaharaan dalam berbagai kontes pelayanan selalu terbuka. Warren Bunnies dalam bukunya On Becoming a Leader (1989) menyatakan seorang pemimpin tidak hanya memperbaiki, tapi juga mengembangkan. Seorang pemimpin tidak hanya fokus pada sistem dan struktur, tapi juga fokus kepada pelaksana kebijakan. Seorang pemimpin tidak hanya melihat keputusan dalam jangka pendek, tapi juga melihat jangka panjang dari keputusan yang diambil (Rago, 1996). Pembentukan jiwa kepemimpinan di level Kasi dan Kepala Kantor KPPN Malang akan membuat implementasi pelaporan basis akrual lebih terjamin.

Dari uraian di atas dapat disimpulkan bahwa faktor disposisi menjadi faktor penghambat dalam implementasi kebijakan. Hambatan ini pertama berasal dari level pelaksana yang mengeluhkan proses rekon online dan pencocokan saldo antar seksi. Hambatan kedua berasal dari level pemimpin, dalam hal ini peringkat jabatan Kasi Vera yang lebih rendah dari Kasi lain dan kurangnya komitmen Kepala KPPN Malang di awal penerapan pelaporan basis akrual.

\subsubsection{Struktur Birokrasi}

Struktur birokrasi menjadi faktor penghambat terakhir pada hampir semua tahapan implementasi pelaporan basis akrual di KPPN Malang. Hambatan ini berasal pada Standar Operating Procedure (SOP). SOP pertama yang menjadi hambatan adalah SOP Penyusunan LKPP pada bagian pencocokan saldo antar seksi dalam penyusunan LKPP. Walau koordinasi yang terjalin sudah baik, namun proses pencocokan saldo ini berjalan lama. SOP kedua yang menjadi hambatan adalah SOP rekonsiliasi online yang tanggal pelaksanaannya belum efisien karena selalu berubah-ubah setiap bulan. Hal ini menimbulkan "kebingungan" jadwal kerja implementor: kapan melakukan rekon; kapan cut off laporan; dan kapan mulai menyusun LKPP. SOP ketiga yang menjadi hambatan adalah belum adanya ketentuan penyusunan
CALK pada LO sebagai laporan berbasis akrual, sehingga mengurangi kualitas akrual pada LKPP.

Ketiadaan informasi akrual sebagai akibat belum adanya SOP yang mengatur penyusunan CALK pada LO dan Neraca bisa mengurangi kesuksesan implementasi pelaporan basis akrual di tahun ketiga ini. Pengguna dan pembaca laporan akan bertanya-tanya terhadap kualitas laporan keuangan yang dihasilkan. Pengguna laporan menginginkan adanya informasi akrual dalam laporan keuangan (Daniels dan Daniels, 1991).Berikut kutipan wawancara dengan Ndaru (penyusun LKPP):

"oh angka itu ya mas. Angka-angka yang beda seperti pada LO dan LRA, saya belum bisa kasih penjelasan mas. Selain ya itu tadi, kan CALK LO belum ada. Tapi itu pasti dari LK-nya satker mas. Kan mereka punya menu jurnal penyesuaian di Aplikasi SAIBA-nya. Nah dari jurnal itu langsung terposting ke LO mereka dan masuk ke LO kita juga”.

\subsubsection{Ringkasan}

Berdasarkan paparan mengenai implementasi pelaporan pemerintah berbasis akrual dengan alat analisis data Model Implementasi Edward III (1980), terdapat beberapa faktor internal yang memengaruhi pelaksanaan implementasi di KPPN Malang. Faktor-faktor tersebut adalah:

Tabel 7

Faktor-faktor yang Mempengaruhi Implementasi Pelaporan Pemerintah Berbasis Akrual pada LKPP Tingkat KPPN Malang

\begin{tabular}{|c|c|}
\hline Faktor & Temuan Penelitian \\
\hline Komunikasi & $\begin{array}{l}\text { Komunikasi yang dilakukan terkait } \\
\text { pelaporan berbasis akrual telah baik } \\
\text { dilakukan. KPPN Malang banyak } \\
\text { melakukan sosialisasi dan koordinasi dalam } \\
\text { melakukan implementasi kebijakan. } \\
\text { Sosialisasi dan koordinasi dilakukan tidak } \\
\text { hanya internal pegawai, tapi juga ke luar } \\
\text { (satuan kerja, Kanwil Ditjen } \\
\text { Perbendaharaan Propinsi Jatim dan Kantor } \\
\text { Pusat Ditjen Perbendaharaan). } \\
\text { Seksi Vera KPPN Malang telah } \\
\text { memanfaatkan secara penuh dukungan } \\
\text { teknologi (whatsapp, facebook dan website) } \\
\text { dalam melakukan koordinasi kebijakan } \\
\text { pelaporan basis akrual. }\end{array}$ \\
\hline $\begin{array}{c}\text { Sumber } \\
\text { Daya }\end{array}$ & $\begin{array}{l}\text { Sumber Daya Manusia } \\
\text { KPPN Malang memiliki SDM yang } \\
\text { cukup secara kuantitas dan kualitas } \\
\text { serta pemahaman yang baik akan } \\
\text { pelaporan basis akrual. } \\
\text { Namun SDM KPPN Malang yang } \\
\text { kebanyakan perempuan berusia di atas } \\
50 \text { tahun dengan tingkat pendidikan } \\
\text { SMA membuat proses mutasi di KPPN } \\
\text { Malang berjalan kaku, sehingga dapat }\end{array}$ \\
\hline
\end{tabular}




\begin{tabular}{|c|c|}
\hline & $\begin{array}{l}\text { menghambat implementasi pelaporan } \\
\text { basis akrual dalam jangka panjang. } \\
\text { Selain itu Jabatan Kepala Seksi Vera } \\
\text { telah kosong selama } 4 \text { bulan. } \\
\text { Sumber Daya Pendukung } \\
\text { A. Sumber Daya Finansial } \\
\text { Seksi Vera KPPN Malang dalam } \\
\text { penyusunan LKPP telah mendapatkan } \\
\text { dana dalam DIPA yang lebih banyak } \\
\text { dibandingkan seksi lain. } \\
\text { B. Sumber Daya Peralatan } \\
\text { Sebagai pemenang kontes pelayanan, } \\
\text { KPPN Malang memiliki ruangan kerja } \\
\text { yang nyaman dan mendukung } \\
\text { implementasi pelaporan basis akrual. } \\
\text { Namun KPPN Malang hanya memiliki } \\
1 \text { printer canggih dalam penyusunan } \\
\text { laporan dan terkadang digunakan seksi } \\
\text { lain. Hal ini sangat rawan sewaktu } \\
\text { penyusunan LKPP. }\end{array}$ \\
\hline Disposisi & $\begin{array}{l}\text { Disposisi para pelaksana kebijakan berada } \\
\text { pada tahap kurang baik terkait proses } \\
\text { rekonsiliasi dan pencocokan saldo antar } \\
\text { seksi. } \\
\text { Disposisi pada level Kepala Seksi } \\
\text { mengalami masalah jika jabatan Kepala } \\
\text { Seksi yang dipegang oleh Kepala Seksi } \\
\text { Bank terus dibiarkan kosong dalam jangka } \\
\text { panjang. } \\
\text { Di level kepala seksi juga terdapat masalah } \\
\text { karena peringkat jabatan Kepala Seksi Vera } \\
\text { yang lebih rendah satu tingkat dibandingkan } \\
\text { Kepala Seksi Lain. }\end{array}$ \\
\hline $\begin{array}{l}\text { Struktur } \\
\text { Birokrasi }\end{array}$ & $\begin{array}{l}\text { SOP Penyusunan LKPP Berbasis Akrual } \\
\text { memiliki permasalahan di bagian } \\
\text { pencocokan saldo kas di LAK dengan saldo } \\
\text { kas di LKP dan Rekening Koran. Hal ini } \\
\text { dikarenakan semenjak basis akrual, hal ini } \\
\text { memerlukan koordinasi yang lebih. } \\
\text { SOP Rekonsiliasi sebagai awal dari proses } \\
\text { konsolidasi laporan dengan satuan kerja } \\
\text { belum diatur dengan PMK. SOP ini masih } \\
\text { sebatas Surat Ditjen Perbendaharaan yang } \\
\text { berubah-ubah setiap bulan. Hal ini } \\
\text { mengurangi keefisienan proses pelaporan } \\
\text { berbasis akrual. } \\
\text { SOP Penyusunan CALK belum mengatur } \\
\text { penyusunan CALK pada LO sebagai } \\
\text { laporan berbasis akrual, sehingga } \\
\text { mengurangi kualitas informasi akrual pada } \\
\text { LKPP. }\end{array}$ \\
\hline
\end{tabular}

\section{Kesimpulan}

Sebagai entitas awal dalam penyusunan LKPP, KPPN Malang menggunakan PP No. 71 Tahun 2010 dan PMK No.177/PMK.05/2015 sebagai kebijakan pokok dalam pelaporan berbasis akrual di LKPP Tahun 2015 dan 2016. KPPN Malang melaksanakan langkah-langkah berikut dalam implementasi kebijakan: persiapan (pembentukan tim rekonsiliasi dan penyusun LKPP, sosialisasi kebijakan); pelaksanaan (rekonsiliasi laporan, koordinasi dengan satuan kerja); pengukuran (pencocokan saldo hasil rekonsiliasi dan lintas seksi internal KPPN); dan pelaporan (penyajian laporan, analisa laporan dan penyusunan CALK).

Hasil penelitian terkait analisis implementasi kebijakan pelaporan basis akrual dengan alat analisis Teori Edward III (1980) menunjukkan faktor pendukung dan penghambat implementasi dari internal KPPN Malang. Faktor-faktor ini adalah: komunikasi, sumber daya, disposisi dan struktur birokrasi.

Faktor internal pertama berasal dari komunikasi kebijakan. Faktor komunikasi di semua tahapan implementasi kebijakan menunjukkan komunikasi telah baik dilakukan. KPPN Malang banyak melakukan sosialisasi dan koordinasi dalam melakukan implementasi kebijakan. Sosialisasi dan koordinasi dilakukan tidak hanya internal pegawai, tapi juga ke luar (satuan kerja, Kanwil Ditjen Perbendaharaan Propinsi Jatim dan Kantor Pusat Ditjen Perbendaharaan). Koordinasi dilakukan dengan memanfaatkan secara penuh dukungan teknologi (whatsapp, facebook dan website).

Melalui analisis sumber daya di semua langkah implementasi kebijakan pelaporan basis akrual (SDM, Finansial dan Peralatan), ditemui beberapa faktor pendukung dan penghambat. Faktor pendukung berasal dari sumber daya finansial, dimana Seksi Vera KPPN Malang mendapatkan porsi anggaran yang lebih besar dibandingkan seksi lain di dalam DIPA KPPN Malang. Faktor penghambat berasal dari SDM dan Peralatan. Proses mutasi di KPPN Malang berjalan kaku sebagai akibat komposisi SDM KPPN Malang yang kebanyakan perempuan berusia di atas 50 tahun dengan tingkat pendidikan SMA. Selain itu Jabatan Kepala Seksi Vera telah kosong selama 4 bulan. Peralatan berupa printer yang canggih pada seksi vera terkadang digunakan seksi lain. Faktor SDM dan Peralatan di atas bisa menjadi rawan dalam jangka panjang penyusunan LKPP.

Dari faktor disposisi di semua tahapan implementasi kebijakan, terdapat hal yang perlu diperhatikan KPPN Malang. Disposisi dari sisi pelaksana berada pada level kurang baik terkait proses rekonsiliasi yang berubahubah tiap bulan dan lamanya proses pencocokan saldo antar seksi. Pada level Kepala Seksi terdapat masalah pada jabatan Kepala Seksi yang dipegang oleh Kepala Seksi Bank selama 4 bulan dan peringkat jabatan Kepala Seksi Vera yang lebih rendah satu tingkat dibandingkan Kepala Seksi Lain.

Terkait faktor struktur birokrasi di semua tahapan implementasi kebijakan, masalah SOP perlu diperhatikan KPPN Malang. SOP Penyusunan LKPP Berbasis Akrual di bagian pencocokan saldo kas di LAK dengan saldo kas di LKP dan Rekening Koran, memerlukan koordinasi 
yang lebih semenjak penerapan basis akrual. SOP rekonsiliasi yang selalu berubah setiap bulan memerlukan Peraturan Menteri Keuangan untuk meningkatkan efisiensi penyusunan pelaporan basis akrual. Terakhir SOP Penyusunan CALK memerlukan penyusunan CALK pada LO untuk meningkatkan kualitas informasi akrual pada LKPP.

Penelitian juga berhasil menemukan kualitas penerapan basis akrual pada pelaporan pemerintah di tahun 2017. Hasil penelitian menunjukkan kualitas basis akrual pada LKPP masih memerlukan perbaikan, yang ditunjukkan dengan ketiadaan informasi akrual pada CALK LO dan Neraca di LKPP.

\section{Daftar Pustaka}

Adhikari, P., Mellemvik. (2011). The Rise and Falls of Accruals: A Case of Nepalese Central Government. Accounting, Auditing \& Accountability Journal. 1 (2): 169-199.

Arnaboldi, M. and Lapsley, I. (2004). Modern Costing Innovations and Legitimation: A Health Care Study. Abacus. 40(1), pp. 1-20.

Arni, Muhammad. (2002). Komunikasi Organisasi. Jakarta: Bumi Aksara.

Asfiansyah, Ahdony. (2013). Strategi Implementasi Akuntansi Akrual pada Pemerintah Daerah (Studi Kasus pada Pemerintah Kota "S"). Tesis. Universitas Brawijaya. Malang.

Athukorala, Sarath Lakshman, dan Barry Reid. (2003). Accrual Budgeting and Accounting in Government and Its Relevance for Developing Member Countries. Asian Development Bank.

Badan Pemeriksa Keuangan. (2016). BPK Memberikan Opini Wajar Dengan Pengecualian Terhadap Laporan Keuangan Pemerintah Pusat. http://www.bpk.go.id/news/bpk-memberikanopini-wajar-dengan-pengecualian-terhadaplaporan-keuangan-pemerintah-pusat.16 Desember 2016.

Carruthers, B. G. (1995). Accounting, Ambiguity, and The New Institutionalism, Accounting, Organizational and Society. 20 (4): 313-328.

Christensen, M., dan Parker, L. (2010). Using Ideas to Advance Professions: Public Sector Accrual Accounting. Financial Accountability and Management. 26 (3): 246-266.

Churchill, M. (1992). Accrual Accounting in the Public Sector. Australian Accountant.

Cortes, J. L. (2006). The International Situation the Adoption of Accrual Budgeting. Journal of Public Budgeting, Accounting and Financial Management.
Daniels, J.D, dan Daniels, C.E. (1991). Municipal Financial Reports: What Users Want. Journal of Accounting and Public Policy. 10: 15-38.

Darwin. (1995). Implementasi Kebijakan. Yogyakarta: Pusat Penelitian Kependudukan UGM.

DiMaggio, P. J., dan Powell, W.W. (1991). The Iron Revisited: Institutional Isomorphism and Collective Rationality in Organizational Fields. Dalam W. W. Powell \& P. J. DiMaggio (editor). The New Institutionalism in Organizational Analysis (p. 63-82). The University of Chicago Press. Chicago.

Dunn, William N. (1998). Muhadjir Darwin (Penyunting). Pengantar Analisis Kebijakan Publik. Yogyakarta: Gadjah Mada University Press.

Edward III, G. C. (1980). Implementing Public Policy. Congressional Querterly Press.

Gorda, IGN. (2004). Manajemen Sumber Daya Manusia. Singaraja: Penerbit STIE Satya Dharma.

Ivancevich, John M., Konopaske, Robert, Matteson, Michael T. (2006). Perilaku dan Manajemen Organisasi. Jakarta: Penerbit Erlangga.

Kantor Pelayanan Perbendaharaan Negara Malang. (2016). Laporan Keuangan Pemerintah Pusat Tahun 2015 (Audited). Malang.

Kantor Pelayanan Perbendaharaan Negara Malang. (2017). Laporan Keuangan Pemerintah Pusat Tahun 2016 (Un-Audited). Malang.

Kementerian Keuangan RI. (2014). Indonesia jadi Negara ASEAN Pertama Terapkan Sistem Akuntansi Berbasis Akrual. http://www.kemenkeu.go.id/en/node/42843. 17 Desember 2016.

Keputusan Dirjen Perbendaharaan No. 191/PB/2013 Tentang Penetapan Peringkat Penilaian Laporan Keuangan Pemerintah Pusat Tingkat Kuasa Bendahara Umum Negara Daerah Kantor Pelayanan Perbendaharaan Negara dan Kantor Wilayah Direktorat Jenderal Perbendaharaan Tahun 2012.

Keputusan Dirjen Perbendaharaan No. 248/PB/2014 Tentang Penetapan Peringkat Penilaian Laporan Keuangan Pemerintah Pusat Tingkat Kuasa Bendahara Umum Negara Daerah Kantor Pelayanan Perbendaharaan Negara dan Kantor Wilayah Direktorat Jenderal Perbendaharaan Tahun 2013.

Keputusan Dirjen Perbendaharaan No. 239/PB/2015 Tentang Rencana Strategis Ditjen Perbendaharaan Tahun 2015-2019.

Keputusan Dirjen Perbendaharaan No. 326/PB/2015 Tentang Penetapan Peringkat Penilaian Laporan Keuangan Pemerintah Pusat Tingkat Kuasa Bendahara Umum Negara Daerah Kantor Pelayanan Perbendaharaan Negara dan Kantor 
Wilayah Direktorat Jenderal Perbendaharaan Tahun 2014.

Keputusan Dirjen Perbendaharaan No. 287/PB/2015 tentang Standar Operasional Prosedur KPPN.

Keputusan Kepala Kanwil Ditjen Perbendaharaan Propinsi Jawa Timur No.145/WPB.16/2016 hal Peringkat Laporan Keuangan Pemerintah Pusat Tingkat KPPN Propinsi Jawa Timur Tahun 2015.

Keputusan Menteri Negara PAN Nomor 63/Kep/M.PAN/7/2003 Tentang Pedoman Umum Penyelenggaraan Publik.

Khan, Abdul and Mayes, Stephen. (2007). Transition to accrual accounting. Public Financial Management Technical Guidance Note, Fiscal Affairs Department.

Kim, P. S., Halligan, J., Cho, N., Oh, C. and Eikenberry, A. M. (2005). Toward Participatory and Transparent Governance: Report on The Sixth Global Forum on Reinventing Government. Public Administration Review. 65(6), pp. 646-654.

Langelo, F., Saerang, D.P.E. and Alexander, S.W. (2015). Analisis Penerapan Standar Akuntansi Pemerintahan Berbasis Akrual dalam Penyajian Laporan Keuangan pada Pemerintah Kota Bitung. Jurnal EIMBA Vol.3 No.1 Maret 2015:1-8.

Lewin, K. (1951). Field Theory in Social Science. Harper and Row. New York.

Lippi, A. (2000). One Theory, Many Practices. Institutional Allomorphism in the Managerialist Reorganization of Italian Local Governments. Scandinavian Journal of Management. 16: 455477.

Mack, Janet dan Ryan, Christine. (2007). Is There An Audience for Public Sector Annual Reports: Australian Evidence? International Journal of Public Sector Management. 20 (2): 134-146.

March, J.G., and Johan, P.O. (1976). Ambiguity and Choice in Organizations. Universitetsforlaget. Bergen.

Muttaqin, Riza. (2015). Upaya Penerapan SAP Akrual dan Perolehan Opini WTP pada Pemerintah Kota Pekalongan: Kajian Berdasarkan Teori Perubahan Organisasi. Tesis. Universitas Brawijaya. Malang.

Nesbakk, L. G. (2010). Accrual Accounting Representations in The Public Sector-A Case of Autopoiesis. Critical Perspectives on Accounting. October 2010. Vol. 12.

Peraturan Menteri Keuangan No.96/PMK.03/2009 Tentang Jenis-jenis Harta yang Termasuk Dalam Kelompok Harta Berwujud Bukan Bangunan untuk Keperluan Penyusutan.

Peraturan Menteri Keuangan Nomor 177/PMK.05/2015 Tentang Pedoman Penyusunan dan Penyampaian Laporan Keuangan Kementerian Negara/Lembaga.
Peraturan Pemerintah Nomor 71 Tahun 2010 Tentang Standar Akuntansi Pemerintah.

Rago, William. V. (1996). Struggles in Transformation: A Study in TQM, Leadership, and Organizational Culture in a Government Agency. Public Administration Review. Vol. 56 (3). pp. 227-234

Rahmawati, N., Made, A. dan Wirshandono, D. (2016). Implementasi Standar Akuntansi Pemerintahan Berbasis Akrual di Sekretariat DPRD Kabupaten Malang Berdasar Peraturan Nomor 71 Tahun 2010. Jurnal Riset Mahasiswa. Universitas Kanjuruhan Malang.

Sari, Lita Permata. (2015). Akrualisasi Sektor Publik: Studi Kasus Pada Pemerintah Daerah Kabupaten Situbondo. Tesis. Universitas Brawijaya. Malang.

Siti-Nabiha, A. K. and Scapens, R. W. (2005). Stability and change: an institutionalist study of management accounting change. Accounting, Auditing and Accountability Journal. 18(1). pp. 44-73.

Subarsono, AG. (2009). Analisis Kebijakan Publik Konsep Teori dan Aplikasi. Yogyakarta: Pustaka Pelajar.

Tohidi, Hamid. and Jabbari, Mohammad Mehdi. (2012). Organizational Culture and Leadership. ProcediaSocial and Behavioral Sciences. Vol. 31. pp. 856860.

Wahyudi. (1995). Manajemen Personalia Perusahaan. (online), (http://mutasi-pegawai-padaperusahaan/com, diakses tanggal 23 Juni 2017)

Yin, R, K. (2013). Case Study Research: Design and Methods. Mudzakir, M Djauzi (penerjemah). Studi Kasus: Desain \& Metodologi. Kota Depok: PT Rajagrafindo Persada.

Yin, R.K. (2014). Studi Kasus: Desain dan Metode (Mudzakir, M.D., Ed). Jakarta: PT. Raja Grafindo Perkasa. 